\title{
Expression of p63, TTF-1 and Maspin in Non-Small Cell Lung Carcinoma and Their Effect on the Prognosis and Differential Diagnosis
}

\author{
Küçük Hücreli Dışı Akciğer Karsinomunda p63, TTF-1 ve Maspin \\ Ekspresyonu - Prognoz ve Ayırıcı Tanı Üzerine Etkileri
}

\author{
Banu YAMAN ${ }^{1}$, Deniz NART ${ }^{1}$, Pervin KORKMAZ EKREN ${ }^{2}$, Gürsel ÇOK ${ }^{2}$, Ali VERAL ${ }^{1}$
}

Department of ${ }^{1}$ Pathology and ${ }^{2}$ Chest Diseases, Ege University Faculty of Medicine, IZMIR, TURKEY

\begin{abstract}
Objective: Lung cancer is still the leading cause of cancer mortality. Antiapoptotic genes and protease inhibitors play an important role in the development of lung cancer.
\end{abstract}

Material and Method: p63, TTF-1 and maspin expression and their role in the differential diagnosis, overall survival, progression-free survival and other clinicopathological characteristics of the patients were investigated in 80 surgically-resected non-small cell lung carcinomas.

Results: The maximal tumor diameter range was $1.5-11 \mathrm{~cm}$ (mean: $4.06 \pm 1.8 \mathrm{~cm}$ ). Forty-five $(56.3 \%)$ tumors were adenocarcinoma, 23 (28.8\%) squamous cell carcinoma, four (5\%) large cell carcinoma, six $(7.5 \%)$ large cell neuroendocrine carcinoma, one (1.2\%) sarcomatoid carcinoma while one was (1.2\%) both adenocarcinoma and squamous cell carcinoma. The patients with advanced TNM stage and a tumor diameter more than $3 \mathrm{~cm}$ had markedly poor survival. Immunohistochemically, p63 staining was present in $87.5 \%$ of squamous cell carcinomas, $4.3 \%$ of adenocarcinomas, $25 \%$ of large cell carcinomas, and $16.7 \%$ of large cell neuroendocrine carcinomas. Similarly, maspin was positive in $66.7 \%$ of squamous cell carcinomas and $17.4 \%$ of adenocarcinomas. The TTF-1 staining rate was higher in adenocarcinomas (84.8\%). There was no immunoreactivity in squamous cell carcinomas $(\mathrm{p}<0.001)$. We found that $\mathrm{p} 63$ and TTF-1 had no significant effect on survival in either tumor group ( $p>0.05)$ while maspin has a negative prognostic effect in adenocarcinoma $(\mathrm{p}=0.048)$.

Conclusion: This study suggests that p63 and TTF-1 are reliable markers in non-small cell lung carcinoma and can be used in differential diagnosis. Maspin has been identified as a prognostic marker in adenocarcinoma. However, more studies are required to elucidate the significance of maspin.

Key Words: Non-small-cell lung carcinoma, p63, TTF-1, Maspin, Prognosis

\begin{abstract}
ÖZ
Amaç: Akciğer kanseri, kanser ölümlerinin önde gelen nedenlerindendir. Antiapopitotik genler ve proteaz inhibitörleri akciğer kanseri gelişiminde önemli role sahiptir.

Gereç ve Yöntem: Seksen opere küçük hücreli dışı akciğer karsinom olgusunda p63, TTF-1 ve maspin ekspresyonunun ayırıcı tanıya olan katkıları, sağkalım ve hastalıksız sağkalım üzerine etkileri ve diğer klinikopatolojik özellikler değerlendirildi.

Bulgular: Ameliyat materyallerinde izlenen tümörlerin çapları

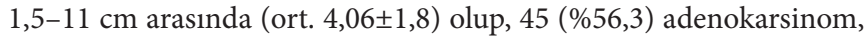
$23(\% 28,8)$ skuamöz hücreli karsinom, dört (\%5) büyük hücreli karsinom, altı $(\% 7,5)$ büyük hücreli nöroendokrin karsinom, bir $(\% 1,2)$ sarkomatoid karsinom ve bir $(\% 1,2)$ adenokarsinom ve skuamöz hücreli karsinom birlikteliğinden oluşmakta idi. İleri TNM evreli ve üç cm’den daha büyük tümör çapı olan olgular daha kötü prognozlu idi. İmmünohistokimyasal incelemede skuamöz hücreli karsinomların $\% 87,5$ 'i, adenokarsinomların $\% 4,3$ 'ü, büyük hücreli karsinomların \%25'i ve büyük hücreli nöroendokrin karsinomların $\% 16,7$ 'si p63 ile pozitif boyand. Benzer olarak maspin de skuamöz hücreli karsinomlarda $\% 66,7$ ve adenokarsinomlarda $\% 27,4$ oranında pozitifti. TTF-1 ekspresyonu, adenokarsinomlarda oldukça yüksek oranda idi $(\% 84,8)$. Skuamöz hücreli karsinomlarda immünreaktivite izlenmedi $(\mathrm{p}<0.001)$. p63 ve TTF-1, her iki tümör grubunda sağkalım üzerine etkili değil iken, maspin immünreaktivitesi adenokarsinomlarda kötü prognostik faktör idi $(\mathrm{p}=0,048)$.
\end{abstract}

Sonuç: Çalışmamızda, p63 ve TTF-1'in küçük hücreli dışı akciğer karsinomlarında güvenilir belirleyiciler oldukları ve ayırıcı tanıda kullanılabilecekleri gösterildi. Maspinin adenokarsinomlarda prognostik bir belirleyici olduğu saptandı. Ancak maspin ile ilgili tüm çalışmalar henüz net değildir ve daha fazla çalışmaya ihtiyaç duyulmaktadır.

Anahtar Sözcükler: Küçük-hücreli-dışı akciğer karsinomu, p63, TTF-1, Maspin, Prognoz
(Turk Patoloji Derg 2015, 31:163-174)

Received : 17.12.2014 Accepted : 21.03.2015
Correspondence: Banu YAMAN

Ege Üniversitesi Tip Fakültesi, Patoloji Anabilim Dalı,

35100, Bornova, IZMIR, TURKEY

E-mail: drbanuyaman@yahoo.com Phone: + 902323903709 


\section{INTRODUCTION}

Lung cancer is one of the major causes of cancer death (1). Lung tumors are histologically heterogeneous tumors with more than one histological type observed in $50 \%$ of the tumors. Lung carcinoma is currently divided into small cell lung carcinoma (SCLC) and non-small cell lung carcinoma (NSCLC). NSCLC cases make up 80-85\% of all lung cancers. The most common histological types of lung carcinoma are squamous cell carcinoma (SCC), adenocarcinoma (AC) and SCLC (2). Targeted therapies in NSCLC vary according to the tumor type, increasing the importance of accurate classification.

Several studies have attempted to understand the mechanism of action of the protease inhibitor and tumor suppressor genes that play a remarkable role in lung tumor pathogenesis. p63 is a member of the p53 tumor suppressor gene family, and its effect on p53 can be agonistic or antagonistic (3). Abnormal expression of p63 has been identified in the oral cavity, skin SCCs, premalignant and invasive squamous lesions, esophagus SCCs, urothelial carcinomas and other tumors (4). p63 has been reported to be highly positive in lung SCCs. Its expression rate is lower in other carcinomas but it can be useful in the differential diagnosis (3).

Thyroid transcription factor-1 (TTF-1) is the thyroidspecific nuclear transcription factor of the thyroglobulin and thyroperoxidase genes (5). Thyroid tumors generally express TTF-1 diffusely while immunoreactivity in lung carcinomas is particularly high in SCLCs and ACs in contrast (6).

Maspin, one of the serine protease inhibitor proteins, leads to reduction in cell permeability, invasion and metastasis (7). It is more commonly expressed in SCCs than in other lung tumors (8). It has also been found to help determine the prognosis of lung ACs (9).

We evaluated the presence of p63, TTF-1 and maspin in non-small cell lung cancer (NSCLC) together with their contribution to predicting the prognosis in this study.

\section{MATERIAL and METHODS}

Eighty patients with surgically resected non-small cell lung carcinoma were selected for this study. The general data of the cases related to TNM stage, treatment methods, follow-up duration and the latest condition was obtained retrospectively. Recurrence and/or metastasis were considered as disease progression.
The macroscopic data of the surgery materials were obtained from Ege University Faculty of Medicine's Pathology Department archive. Five-micron sized sections were obtained from paraffin blocks fixed with formalin, stained with hematoxylin \& eosin and re-evaluated. The 2004 Lung Tumor Classification of the World Health Organization was used as the basis when determining the histological type of the tumors. Two separate tumor foci including SCC and AC were observed in one case, resulting in 81 tumor foci to undergo statistical analysis.

Immunohistochemistry: A paraffin block containing a positive internal control and reflecting the tumor tissue characteristics was chosen. Immunohistochemical (IHC) staining was performed on 5-mm-thick formalin-fixed paraffin-embedded sections, using an avidin-biotin immunoperoxidase technique, after deparaffinization in xylene and rehydration through graded alcohols. A standard HRP multimer-based hydrogen peroxide substrate without biotin, containing 3,3'-diaminobenzidinetetrahydrochloride (DAB) chromogen (ultraView ${ }^{\text {Tw }}$ Universal DAB Detection Kit, Catalogue number 760-500, Ventana Medical Systems, Tucson, AZ) and a fully automatic immunohistochemical staining device (Ventana BenchMark XT, Ventana Medical Systems, Tucson, AZ) were used for visualization. Microwave-mediated antigen retrieval in $10 \mathrm{mM}(\mathrm{pH}$ 6.0) citrate buffer for 15 minutes and endogenous peroxidase application using $0.3 \%$ hydrogen peroxide were performed. Sections were incubated with p63 (clone 4A4, neomarkers, 1:200 dilution, catalogue number: MS-1081-P), TTF-1 (clone 8G7G3/1, Dako, Carpinteria, CA, 1:200 dilution, catalogue number: M3575) and maspin (clone EAW24, Neomarkers, 1:20 dilution, catalogue number: MS-1767-S). Only primary antigens were administered manually and the sample was incubated at $37^{\circ} \mathrm{C}$ for 32 minutes. Finally, sections were counterstained with hematoxylin.

Bronchial basal cells were used as the internal positive control for p63 while type II pneumocytes and bronchial basal cells were utilized for TTF-1 and bronchial basal cells and the myoepithelial cells of peribronchial acinar cells were used for maspin. The positive control was the cervix squamous epithelium for p63, thyroid follicular cells for TTF-1, and the myoepithelial and basal cells of the normal breast and prostate tissues for maspin. Samples on which primary antibody was not administered were considered negative control.

EvaluationofImmunohistochemistry:Immunohistochemical evaluation was performed by two pathologists who were blinded to the clinical data. Nuclear p63 and TTF-1 
staining, and cytoplasmic and/or nuclear maspin staining were regarded as positive. In accordance with the criteria reported by Au et al. (10) and Berghmans et al. (11), the immunoreactivities were semi-quantitatively assessed by the percentage of stained tumor cells. Tumors were considered immunopositive if more than $5 \%$ of tumor cells were stained at least weakly. No interobserver variability was accepted.

Statistical Analysis: All statistical analyses were performed using the Statistical Package for the Social Sciences, version 15.0 for Windows (SPSS Inc., Chicago, IL). The significance of the relationship between expression and clinicopathological parameters was evaluated with univariate analyses using Pearson's chi-square test and Fisher's exact probability test. The univariate (Log-rank, Mantel-Cox) tests, Kaplan-Meier survival curves, and the multivariate analysis using Cox's proportional hazards model were used to evaluate the effect on postoperative survival rates and recurrences. There were only a few study patients with a tumor diagnosis apart from SCC and AC. Statistical analyses on the type of tumor and other variables were therefore solely applied to the SCC and $\mathrm{AC}$ groups. A p value of 0.05 or less was considered as statistically significant.

\section{RESULTS}

The age range of the 80 patients was $35-86$ years (mean $59 \pm 9.7$ years). The clinical and histopathological features are presented in Table I.

All materials were from wedge resection, segmentectomy or lobectomy procedures. Neoadjuvant chemotherapy had been administered to 13 patients. Clinical follow-up information was present for all patients. The mean follow-up duration was $41.4 \pm 26.6$ months (minimum one, maximum 91 months). Thirty-three (41.3\%) patients died, after one to 67 months. Overall survival (OS) was $59.4 \pm 4.3$ months and progression-free survival (PFS) 61.9 \pm 4.3 months (0-91 months). The patients who had 0 month survival had been diagnosed with brain metastasis and formed the Stage-IV group. Recurrence was seen in $12(15 \%)$ and metastasis in $16(20 \%)$ patients. We had $52(65 \%)$ patients who were healthy at the end of the follow-up period.

The average OS values were $59.00 \pm 14.6$ months, $59.43 \pm 6.2$ months, $55.59 \pm 5.9$ months and $31.44 \pm 7.7$ months while the PFS values were $58.85 \pm 14.6$ months, $64.25 \pm 6.1$ months, 55.64 \pm 5.2 months and $31.07 \pm 7.3$ months for the 35-49 years, 50-59 years, 60-69 years and 70 and over years age groups respectively. Increased age was related to decreased survival but this relationship was not statistically significant ( $p>0.05$ for each).
Table I: Clinical and histopathological features of the patients

\begin{tabular}{|l|c|c|}
\hline $\begin{array}{l}\text { Clinical and histopathological } \\
\text { features }\end{array}$ & $\begin{array}{c}\text { Number } \\
\text { of cases } \\
\text { (n) }\end{array}$ & $\begin{array}{c}\text { Percentage } \\
\text { (\%) }\end{array}$ \\
\hline Age & 8 & 10.0 \\
\hline $35-49$ & 31 & 38.8 \\
\hline $50-59$ & 32 & 40.0 \\
\hline $60-69$ & 9 & 11.3 \\
\hline$\geq 70$ & & \multicolumn{2}{|l|}{} \\
\hline
\end{tabular}

\section{Gender}

\begin{tabular}{|l|c|c|}
\hline Male & 71 & 88.8 \\
\hline Female & 9 & 11.2 \\
\hline
\end{tabular}

\section{Diameter of tumours}

\begin{tabular}{|l|l|l|}
\hline$\leq 3 \mathrm{~cm}(\mathrm{~T} 1)$ & 29 & 35.8 \\
\hline$>3 \mathrm{~cm}$ & 52 & 64.2 \\
\hline
\end{tabular}

Latest health status

\begin{tabular}{|l|c|c|}
\hline Alive & 47 & 58.7 \\
\hline Ex & 33 & 41.3 \\
\hline Distant metastases & 16 & 20.0 \\
\hline Present & 64 & 80.0 \\
\hline Absent & 12 & 15.0 \\
\hline Recurrence & 68 & 85.0 \\
\hline Present & 68
\end{tabular}

\begin{tabular}{|l|c|c|}
\hline Histopathological type & \multicolumn{1}{l|}{} \\
\hline Squamous cell carcinoma & 23 & 28.8 \\
\hline Adenocarcinoma & 45 & 56.3 \\
\hline Large cell carcinoma & 4 & 2.5 \\
\hline Large cell neuroendocrine carcinoma & 6 & 7.5 \\
\hline Sarcomatoid Carcinoma & 1 & 1.2 \\
\hline AC + SCC & 1 & 1.2 \\
\hline
\end{tabular}

\begin{tabular}{|l|l|l|}
\hline Stage & \multicolumn{1}{|l|}{} \\
\hline Stage I & 38 & 47.5 \\
\hline Stage II & 12 & 15.0 \\
\hline Stage III & 16 & 20.0 \\
\hline Stage IV & 14 & 17.5 \\
\hline \multicolumn{2}{|l|}{} \\
\hline Lymph node metastasis & 22 & 27.5 \\
\hline Absent & 58 & 72.5 \\
\hline
\end{tabular}

AC: Adenocarcinoma, SCC: Squamous cell carcinoma

Histopathological Findings: The mean tumor diameter was $4.06 \pm 1.8 \mathrm{~cm}(1.5-11 \mathrm{~cm})$ and more than one tumor focus was found in eight (10\%) cases. Two different tumor types (AC and SCC) were observed in one case. 
The percentages of the tumor subtypes are shown in Figure 1A-E. Twenty (43.5\%) patients with AC and 9 (37.5\%) patients with SCC died as a result of their disease. Mean OS was 57.9 months in AC and 58.5 months in SCC, while mean PFS was 62.3 and 57.4 months respectively. There was no statistically significant difference $(\mathrm{p}=0.65$ and $\mathrm{p}=0.89$, respectively).

The overall survival was decreased together with higher recurrence and metastasis rates in patients with higher TNM stage. Tumor stage, tumor diameter, the presence of lymph node metastasis and the relationship with OS and
PFS are shown in Table II and Figure 2. Mean OS was 71.3 months in tumors $\leq 3 \mathrm{~cm}$ and 50.0 months in tumors $>3 \mathrm{~cm}$ $(p=0.005)$. Nevertheless, there was no significant difference regarding PFS periods $(\mathrm{p}=0.73)$.

The mean OS was higher in cases with no lymph node metastasis (61.9 months) compared to those with metastasis (48.1 months) but there was no statistically significant difference $(\mathrm{p}=0.29)$. PFS was 54.7 months in the group with metastasis and 62.6 months in the group with no metastasis $(\mathrm{p}=0.76)$.

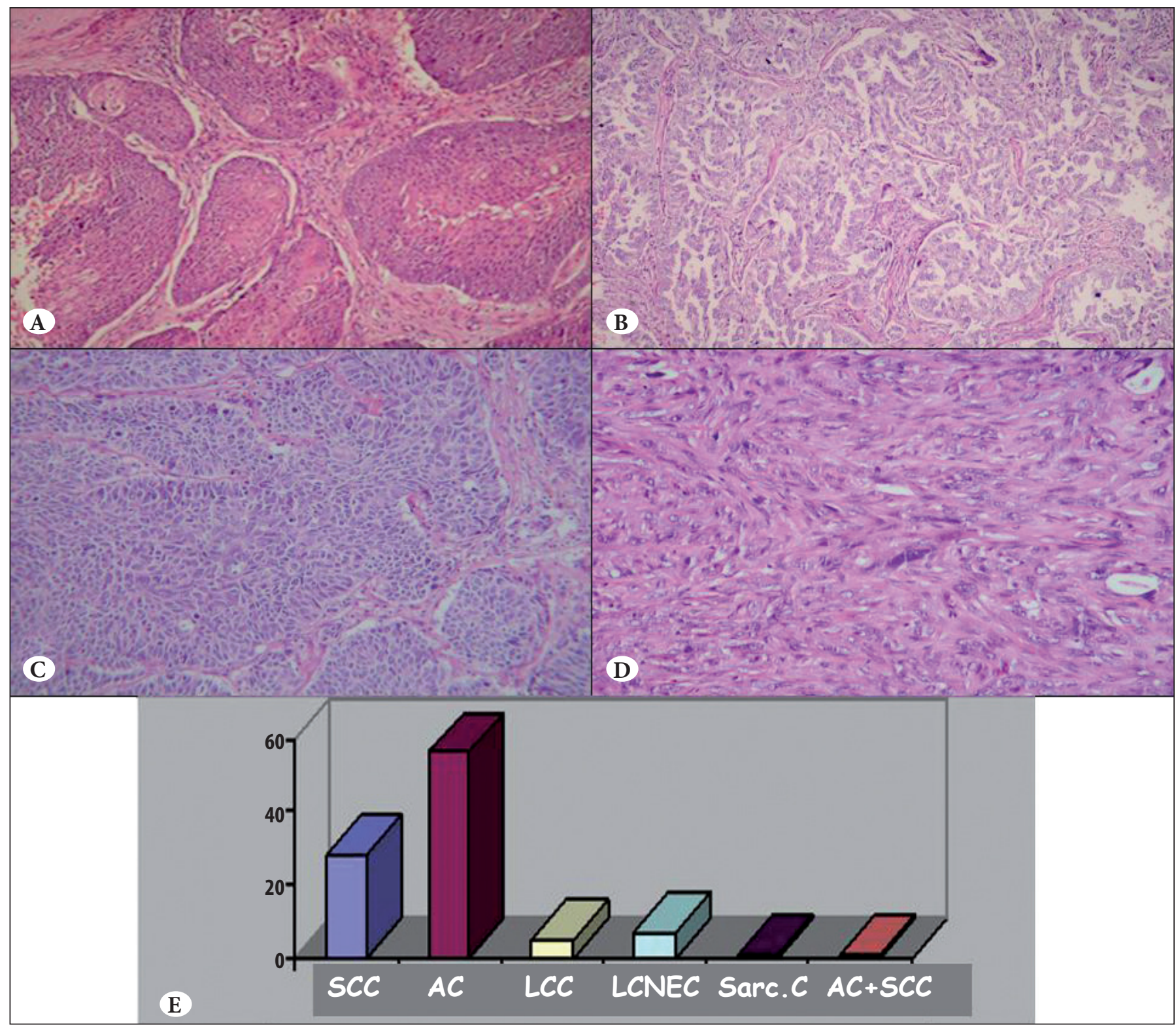

Figure 1: Tumor types and percentages. A) Squamous cell carcinoma (H\&E; x100). B) Adenocarcinoma (H\&E; x100). C) Large cell neuroendocrine carcinoma (H\&E; x100). D) Sarcomatoid carcinoma (H\&E; x200). E) Schematic representation of the tumor type distribution. 
Table II: The relationship amid overall survival- progression free survival and stage, diameter of tumour and lymph node metastasis

\begin{tabular}{|c|c|c|c|c|c|c|c|}
\hline \multirow{2}{*}{ Parameters } & \multirow[b]{2}{*}{$\mathbf{n}$} & \multicolumn{3}{|c|}{ Recurrence-Metastasis } & \multicolumn{3}{|c|}{ Latest health status } \\
\hline & & No $(\%)$ & Yes (\%) & $\mathbf{p}$ & $\mathrm{Ex}(\%)$ & Alive (\%) & $\mathbf{p}$ \\
\hline Stage & & & & 0.005 & & & $<0.001$ \\
\hline Stage II & 12 & $7(58.3)$ & $5(41.7)$ & & $7(58.3)$ & $5(41.7)$ & \\
\hline Stage III & 16 & $10(62.5)$ & $6(37.5)$ & & $8(50)$ & $8(50)$ & \\
\hline$\leq 3 \mathrm{~cm}$ & 29 & $18(62.1)$ & $11(32.9)$ & & $6(20.7)$ & $23(79.3)$ & \\
\hline$>3 \mathrm{~cm}$ & 52 & $35(67.3)$ & $17(32.7)$ & & $27(51.9)$ & $25(48.1)$ & \\
\hline Lymph node metastasis & & & & 0.33 & & & 0.87 \\
\hline Present & 58 & $38(65.5)$ & $20(34.5)$ & & $22(37.9)$ & $36(62.1)$ & \\
\hline
\end{tabular}
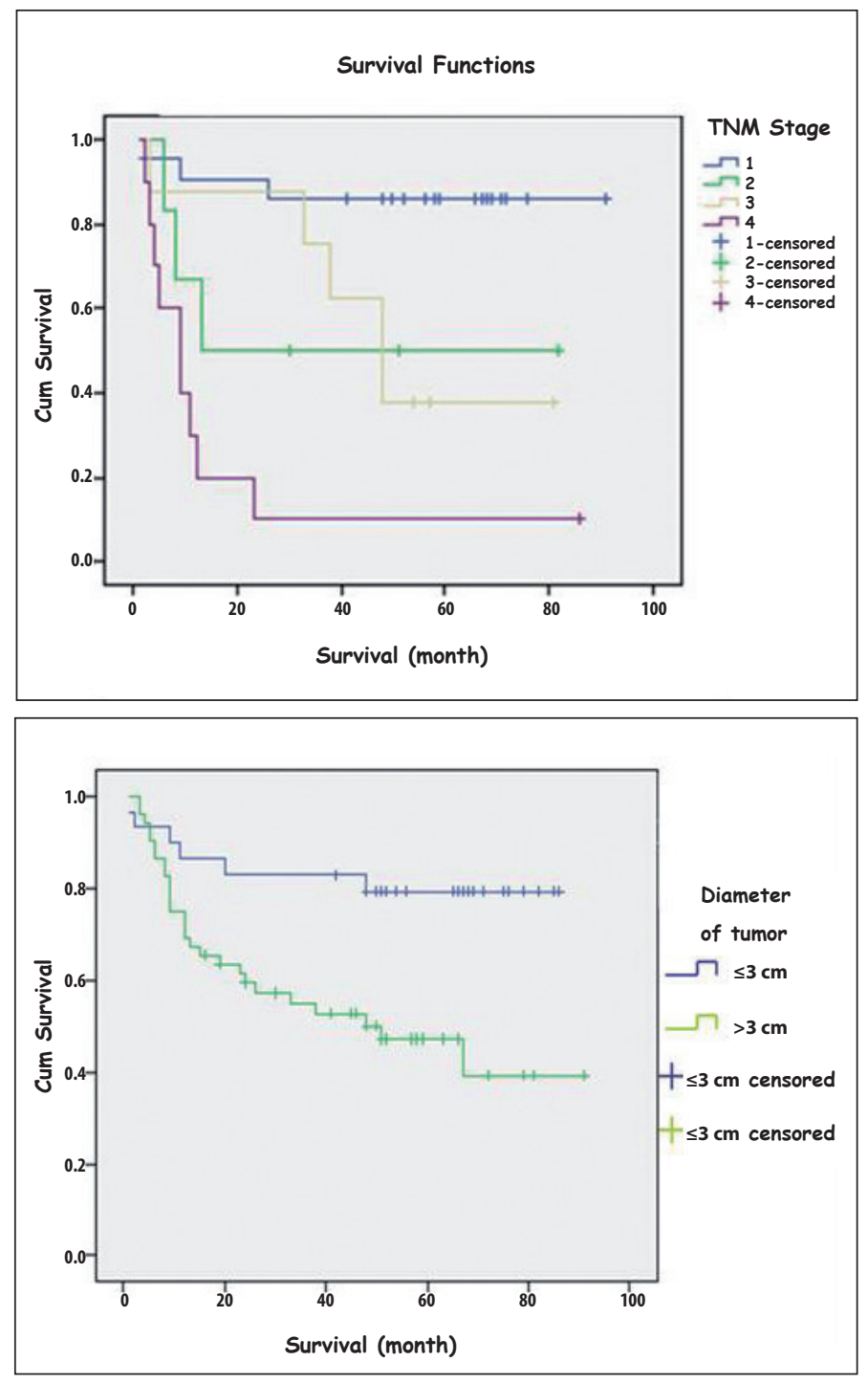

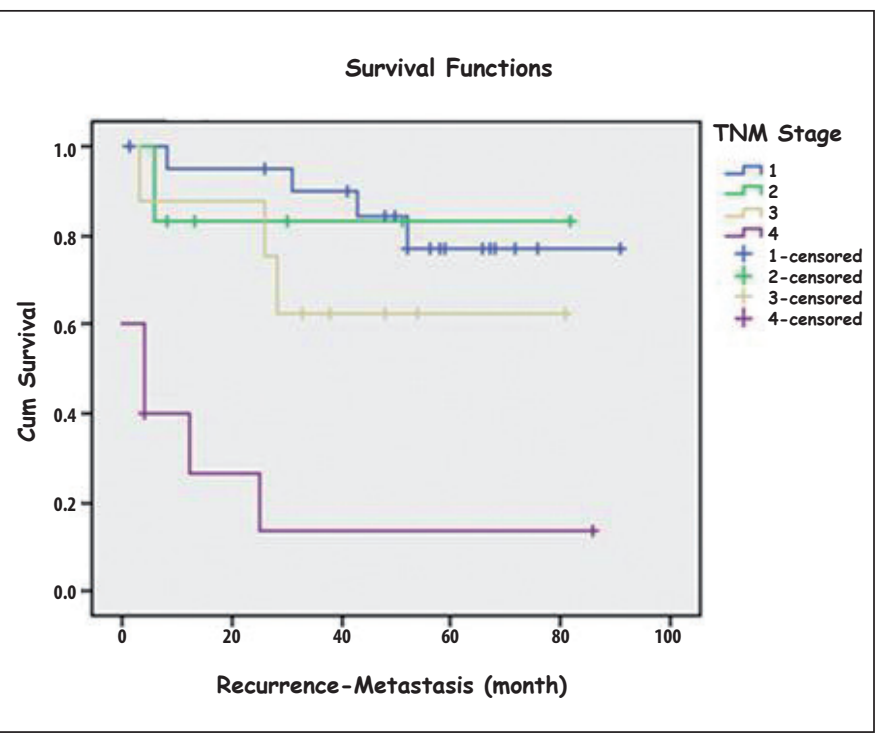

Figure 2: The relationship between overall survival-progression free survival and the tumor stage and the diameter. 
Multivariate analysis for OS and PFS revealed that only tumor stage was an independent prognostic indicator (OS: risk ratio, 5.69; 95.0\% confidence interval [CI], 2.120-15.28; $\mathrm{p}=0.001$; and PFS: risk ratio, 3.16; 95.0\% CI, 1.38-9.52; $\mathrm{p}=0.009$ ). The other parameters had no significant effect on OS or PFS.

The immunoreactivity of p63, TTF-1, and maspin in tumor subtypes is shown in Table III and Figure 3A-I. p63 was positive at a high rate in SCCs and this was statistically significant $(\mathrm{p}<0.001)$. The sensitivity of $\mathrm{p} 63$ for SCC was $87.5 \%$, and the specificity was $95.7 \%$.

TTF- 1 was negative in all SCCs and it was a useful biomarker for AC with $84.8 \%$ sensitivity and $100 \%$ specificity. TTF- 1 being negative in SCCs and positive in ACs was markedly statistically significant $(\mathrm{p}<0.001)$.

Evaluating the immunoreactivity of maspin showed that the positive staining rate was statistically significantly higher in SCCs when compared to ACs as with p63 ( $\mathrm{p}<0.001)$. The sensitivity of maspin for SCC was $66.7 \%$, and the specificity was $82.6 \%$. Maspin was both nuclear and cytoplasmic positive in $69.2 \%(18 / 26)$ of SCC cases. Two AC cases were both nuclear and cytoplasmic positive, two were only nuclear positive and four were only cytoplasmic positive. Staining was of both cytoplasmic and nuclear in two cases with LCC.

The combination of p63 and TTF-1 seems to be useful for differentiating SCC from AC with $85.7 \%$ sensitivity and $97.1 \%$ specificity. There was a statistically significant relationship between p63 and TTF-1 expression and the tumor type $(\mathrm{p}<0.001)$ in both SCC and AC.

Both p63 and maspin staining rates were high in SCC.
We found that $\mathrm{p} 63$, TTF-1 and maspin had no effects on OS or PFS ( $p>0.1$ for each) when tumor type was not taken into account. We studied each marker for its impact on OS and PFS (Table IV) in the SCC and AC groups. TTF- 1 and p63 had no significant effect ( $p>0.05)$ on OS and PFS in the two tumor types.

Maspin showed a significant difference between two histological types. Whilst maspin positivity had no effect in the SCC group, the OS $(\mathrm{p}=0.048)$ and survival duration $(\mathrm{p}=0.05)$ of maspin positive cases were significantly lower than maspin negative cases in the AC group with OS durations of $62.8 \pm 6.1$ months and $27.12 \pm 7.1$ months respectively (Figure 4A-B). Nonetheless, maspin staining had no impact on PFS in either tumor group ( $\mathrm{p}>0.05)$.

Our multivariate analysis on overall survival revealed that only tumor diameter was an independent indicator of poor prognosis (risk ratio, 4.14; 95.0\% CI, 1.45-11.84; $\mathrm{p}=0.008$ ). All other parameters (tumor type, p63, TTF-1 and maspin) had no effect on overall survival. There was no independent prognostic factor affecting progression-free survival $(\mathrm{p}>0.05)$.

\section{DISCUSSION}

Lung cancer is the most common cancer type throughout the world. According to the data from the WHO, the male/ female ratio is 2.7 (2). Lung cancer takes second place among general causes of death and the five-year survival rate is 10$13 \%$. Overall survival is decreased in higher tumor stages $(12,13)$. A study from 2001 with 1600 consecutive lung cancer cases reported the five-year survival rate as $57-67 \%$ for Stage-II and 23\% for Stage-III. Age, tumor stage, diameter, differentiation of tumor, and lymph node metastasis were prognostic factors for these patients (14). Another study

Table III : Immunoreactivity of tumour subtypes with p63, TTF-1 and maspin

\begin{tabular}{|l|c|c|c|c|c|c|c|}
\hline \multirow{2}{*}{} & \multicolumn{2}{|c|}{$\mathbf{p 6 3}$} & \multicolumn{2}{c|}{ TTF-1 } & \multicolumn{2}{c|}{ Maspin } & Total \\
\cline { 2 - 8 } & $\begin{array}{c}\text { Positive } \\
\mathbf{n} / \%\end{array}$ & $\begin{array}{c}\text { Negative } \\
\mathbf{n} / \%\end{array}$ & $\begin{array}{c}\text { Positive } \\
\mathbf{n} / \%\end{array}$ & $\begin{array}{c}\text { Negative } \\
\mathbf{n} / \%\end{array}$ & $\begin{array}{c}\text { Positive } \\
\mathbf{n} / \%\end{array}$ & $\begin{array}{c}\text { Negative } \\
\mathbf{n} / \%\end{array}$ & $\mathbf{n}$ \\
\hline SCC & $21(87.5 \%)$ & $3(12.5 \%)$ & - & $24(100 \%)$ & $16(66.7 \%)$ & $8(33.3 \%)$ & 24 \\
\hline AC & $2(4.3 \%)$ & $44(95.7 \%)$ & $39(84.8 \%)$ & $7(15.2 \%)$ & $8(17.4 \%)$ & $38(82.6 \%)$ & 46 \\
\hline LCC & $1(25 \%)$ & $3(75 \%)$ & $1(25 \%)$ & $3(75 \%)$ & $2(50 \%)$ & $2(50 \%)$ & 4 \\
\hline LCNEC & $1(16.7 \%)$ & $5(83.3 \%)$ & $4(66.7 \%)$ & $2(33.3 \%)$ & - & $6(100 \%)$ & 6 \\
\hline Sarcom. C & - & $1(100 \%)$ & $1(100 \%)$ & - & - & $1(100 \%)$ & 1 \\
\hline Total & $25(30.9 \%)$ & $56(69.1 \%)$ & $45(55.6 \%)$ & $36(44.4 \%)$ & $26(32.1 \%)$ & $55(67.9 \%)$ & 81 \\
\hline \multicolumn{2}{|c|}{$\mathbf{p}<\mathbf{0 . 0 0 1}$} & \multicolumn{2}{|c|}{$\mathbf{p}<\mathbf{0 . 0 0 1}$} & \multicolumn{2}{c|}{$\mathbf{p}<\mathbf{0 . 0 0 1}$} & \\
\hline
\end{tabular}

SCC: Squamous cell carcinoma, AC: Adenocarcinoma, LCC: Large cell carcinoma, LCNEC: Large cell neuroendocrine carcinoma,

Sarcom. C: Sarcomatoid carcinoma 


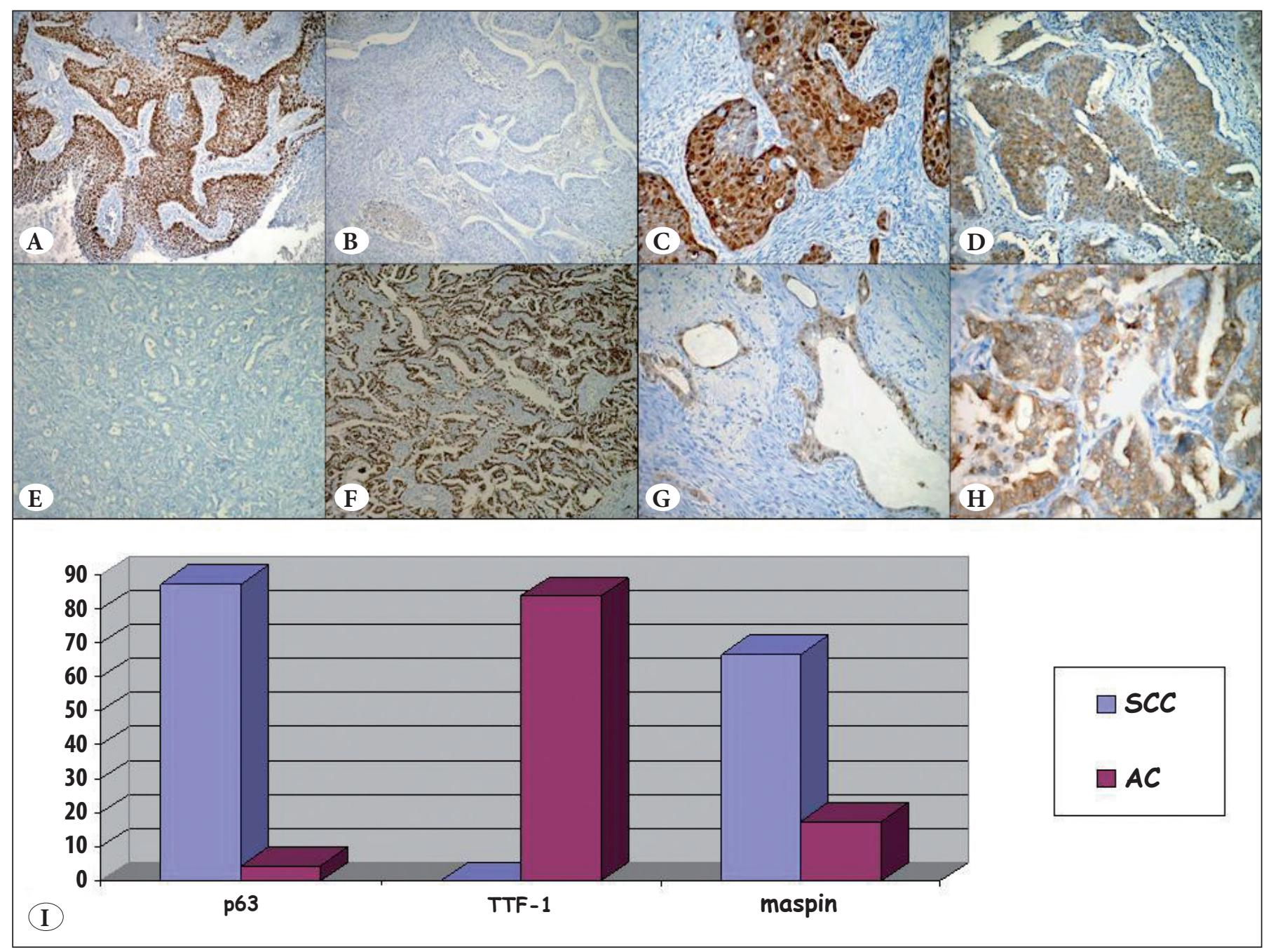

Figure 3: The immunoreactivity in tumor types. A) p63 immunoreactivity in squamous cell carcinoma (SCC) (p63x100). B) Negative staining for TTF-1 in SCC (TTF-1; x100). C) Nuclear and cytoplasmic immunoreactivity for Maspin in SCC (Maspin; x200). D) Only cytoplasmic staining for Maspin in SCC (Maspin; x200). E) Negative staining for p63 in adenocarcinoma (AC) (p63; x100). F) TTF-1 immunoreactivity in AC (TTF-1; x100) G) Nuclear and cytoplasmic immunoreactivity for Maspin in AC (Maspin; x200). H) Only cytoplasmic staining for Maspin in AC (Maspin; x200) I) The graphic shows the rate of positive immunostaining in tumor types

on NSCLC found age, male gender, tumor differentiation and low socioeconomic status to be associated with a poor prognosis (15). We found the stage and diameter of the tumor to be statistically significant parameters for OS and PFS in our study, similar to the literature.

p63 is a 25-exon gene localized in chromosome $3 \mathrm{q} 27-29$ (3) and modulates genes concerning the cell cycle and apoptosis (16). It is also called p40, p51, KET, and p73L $(16,17)$. p63 has been reported to exist at a high rate in the basal cells of some human epithelial tissues with its $\mathrm{N}$-Terminal transactivation part incomplete. These features make it likely to possess dominant negative effects with p53 (17). The "two genes in one gene" term has been used for p63 as it has both agonistic and antagonistic effects (3). p63 is highly expressed in the skin, cervix, vagina, tongue, esophagus, breast, basal cell nuclei of the ureter and lymphoid tissues $(17,18)$. Basal, suprabasal cells and terminally differentiated cells in the bronchi stain positively with p63 (19). Abnormal expression of p63 has been defined in the oral cavity, skin SCCs, premalignant and invasive squamous lesions of the cervix, esophagus SCCs, urothelial carcinoma and also other tumors (4, 1921). There are a number of studies indicating that lung SCC and bronchial epithelial dysplasia show positive p63 expression $(3,4,19,22-29)$. p63 is reported to be markedly positive in lung SCCs while quite low in other carcinomas and therefore a potential determinant in the differential diagnosis. Pelosi et al. (21) identified the positivity rate in 
Table IV : The impacts of markers p63, TTF-1 and Maspin on survival of patient with squamous cell carcinoma and adenocarcinoma.

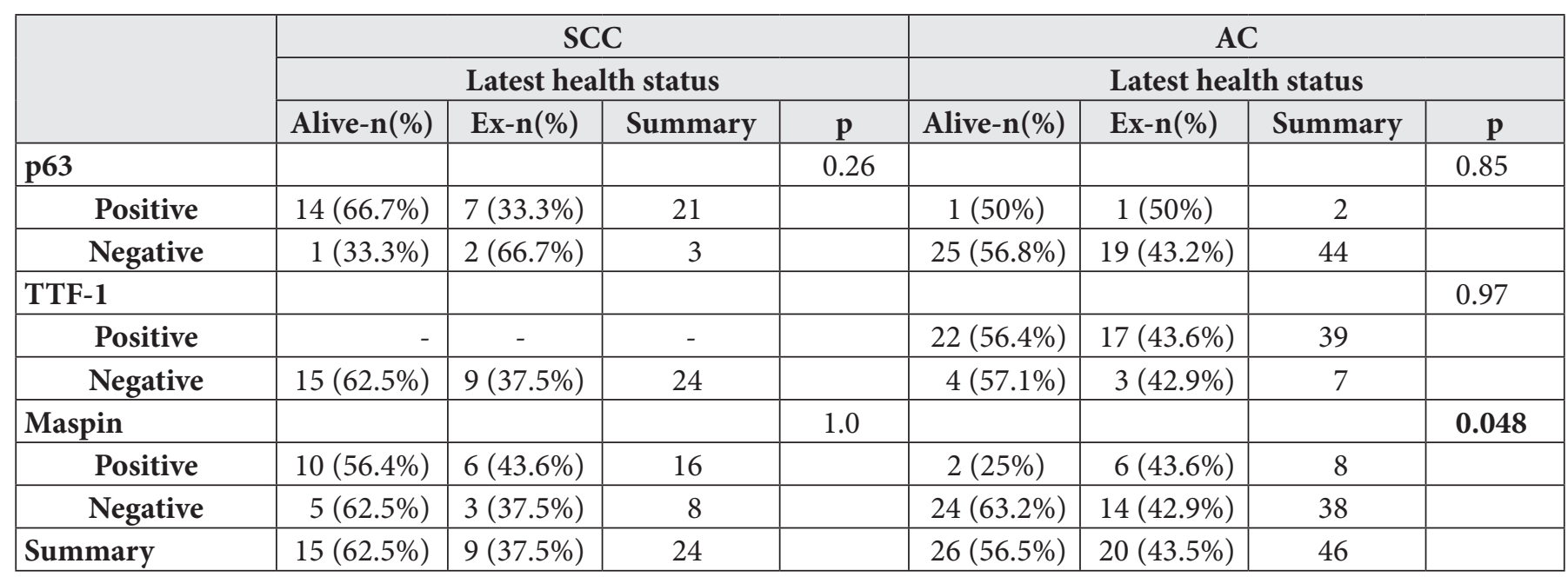

SCC: Squamous cell carcinoma, AC: Adenocarcinoma

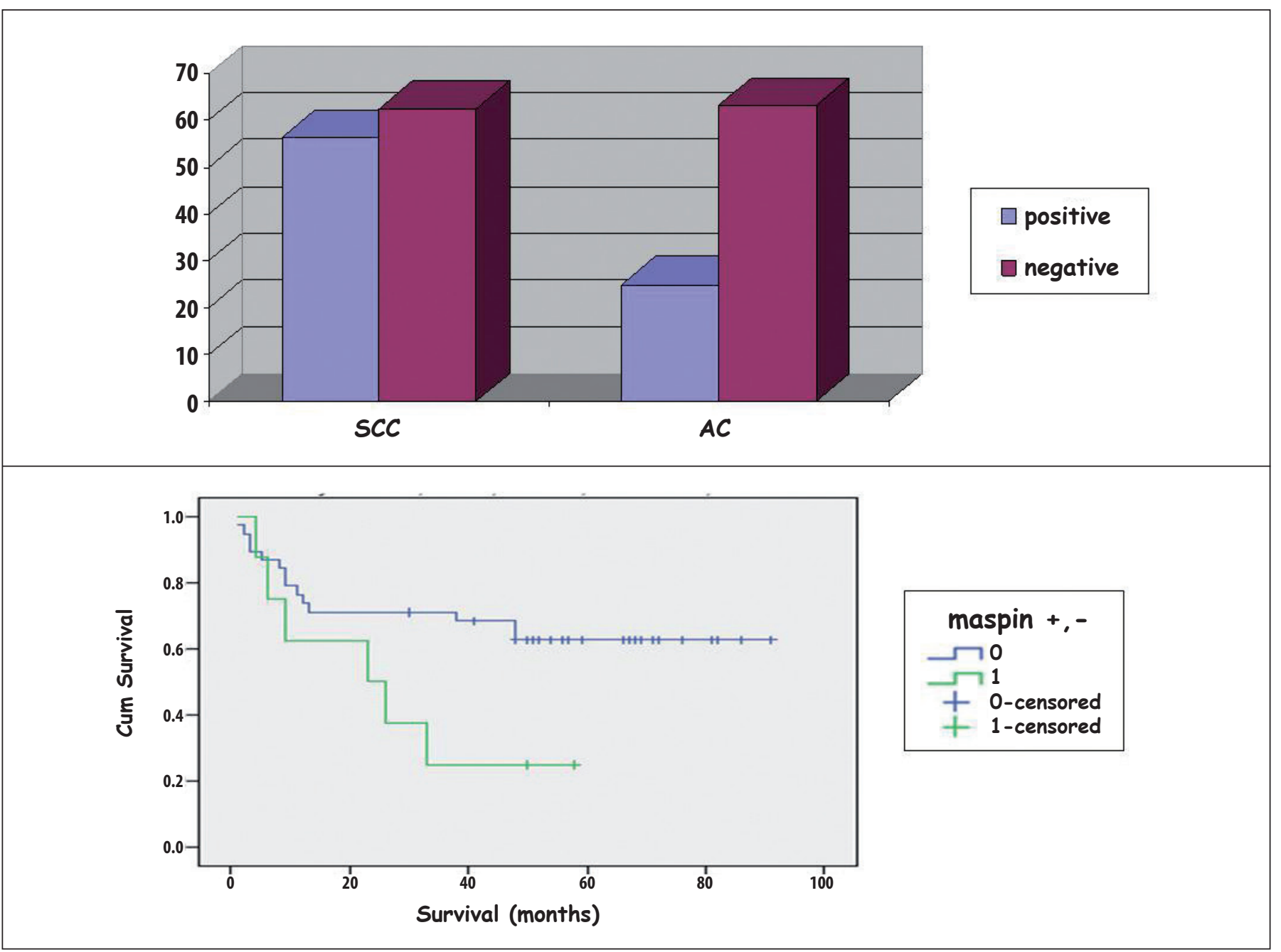

Figure 4: A) The immunoreactivity rate for maspin in squamous cell carcinoma and adenocarcinoma. B) The relationship of maspin and overall survival in cases with adenocarcinoma. 
SCCs as $92.4 \%$. Furthermore, they found that the positivity rate to be increased in less differentiated neuroendocrine carcinomas. However, they did not find p 63 to be associated with survival in NSCLC cases. No p63 staining was found in ACs in some studies while others reported positivity rates of $10 \%$ to $65 \%(3,4,10,19,21,24-27,30-32)$. However, studies reporting negative results with $\mathrm{p} 63$ in ACs had quite low numbers of patients compared to those with positive results where the number was 70 to 90 . The p63 expression increases in neuroendocrine carcinomas (carcinoid tumor, LCNEC, SCLC) as the differentiation decreases (10, 19, 21). However, one study reported higher p63 expression in LCNEC than in SCLC (33). In addition, p63 expression could not be shown in SCLCs in some studies $(27,34,35)$. The positive p63 staining in LCNECs and in other some neuroendocrine carcinoma cases indicates that the origin of these tumors could be related to p63-conditioned stem cells (21). The occurrence of combined variants and of neuroendocrine features in NSCLC also supports a common origin of these tumors with NSCLC. The percentage of p63 positive cases in our study was $87.5 \%$ for SCC and $4.3 \%$ for AC. The number of cases in our study puts it between the group of studies with 70-90 AC cases where the p63 positivity rate was $15-65 \%$ and the group with low numbers of cases where p63 results were negative. We believe more studies with larger numbers of cases are required to clarify p63 staining in ACs.

We discovered a statistically significant difference between p63 staining rates of SCCs and ACs on cross comparison. This finding indicates that p63 can be useful in the differential diagnosis of small bronchoscopic biopsies.

The impact of p63 on the prognosis has also been investigated and increased expression has been reported to be associated with increased survival in SCCs $(3,10)$. In contrast, some studies report no effect on survival $(19,21$, 23). We did not find a significant difference between OS and PFS.

TTF-1 is a tissue-specific nuclear transcription protein localized in chromosome $14 \mathrm{q} 13(11,35,36)$. TTF-1 plays a key role in the early differentiation and morphogenesis of the thyroid, lung, brain and pituitary gland $(5,37)$. It is expressed in all epithelial cells of the lung in the course of embryogenesis (11). TTF-1 inactivation has been reported to cause tracheoesophageal fistula, pulmonary branching disorders and rarely pulmonary hypoplasia (37). TTF-1 expression is very high in lung and thyroid cancers. TTF1 is generally expressed diffusely in thyroid tumors but TTF-1 immunoreactivity varies according to tumor type in lung tumors (6). The TTF-1 immunoreactivity rate in primary lung ACs has been reported to be $60 \%$ to $100 \%$ $(6,38-41)$. Studies reporting a lower staining percentage have emphasized the reason as TTF-1 immunoreactivity being lower in mucinous ACs compared to nonmucinous cases (38-42). TTF-1 is widely utilized in the identification of ACs of lung origin as TTF-1 has been determined to be negative in extra-pulmonary ACs other than some rare ovarian carcinomas $(6,43)$. TTF-1 is also used as a marker in the differential diagnosis of lung adenocarcinomas and pleural mesothelioma $(6,36)$. While TTF-1 expression is less frequently seen (0-30\%) in LCCs of the lung $(39,40$, $44)$, this rate is even lower (0-21\%) in SCCs of the lung (6, $36,38-40,44)$.

In parallel with previous studies, we found TTF-1 to be positive in $\mathrm{AC}$ cases on a large scale but negative in all SCC cases. Three of our seven TTF-1 negative AC cases were mucinous and two were poorly differentiated. TTF1 immunoreactivity generally does not affect survival according to other reports $(11,41)$. TTF- 1 positivity has been found to statistically significantly increase survival in the NSCLC group (36). However, TTF-1 positive occurrences were reported to have better prognosis in another study but the difference was not statistically significant in terms of survival (38). TTF-1 immunoreactivity did not affect the OS or PFS in our study.

Maspin is localized at chromosome 18q21-3 that contains 10 serpins. It is active in cell transition, invasion and metastasis (7). Maspin is largely an intracellular protein that is soluble in the cytoplasm and is also found in association with secretory vesicles (45). Maspin can be present at various locations in the cell. It is especially localized in the cell cytoplasm in breast epithelium cells but can also be observed in the nuclei of myoepithelial cells, secretory vesicles and also on the surface of cells (46). Maspin is also present in normal breast and prostate epithelium cells and was initially found to be decreased in invasive and metastatic breast and prostate cancers (9, $47,48)$. In vitro studies led to maspin's characterization as a class II tumor suppressor based on its ability to inhibit cell invasion, promote apoptosis, and inhibit angiogenesis and pericellular proteolysis in contrast to other serpins $(46,47)$. Some experimental studies have revealed that maspin prevents the development of malignant tumors and/or their progression by a p53-dependent pathway and the inhibition of plasminogen activation and angiogenesis (48). Nakawaga et al. (48) reported a correlation between the levels of maspin and p53. 
There are quite a few studies on maspin in primary lung cancers. Maspin is identified in the basal cells of the bronchial epithelium and the myoepithelial cells of bronchial glandular acini in normal lung tissues. In contrast, it is negative in peripheral lung cells $(48,49)$. Maspin is conspicuously expressed at a higher rate in lung SCCs compared to ACs $(7,8,44,48,50-52)$. We also established maspin to be statistically significantly more commonly positive in SCCs. Hiroshima et al. (33) found 13/17 LCNEC cases to stain with maspin and maspin expression to have unfavorable prognostic significance. Our six LCNEC cases were negative with maspin.

Maspin can be expressed at various locations within a normal cell. Only nuclear, only cytoplasmic, and nuclear and/or cytoplasmic maspin expressions have been compared with the types of tumor in various NSCLC studies $(9,45,53)$. Maspin staining is usually nuclear and cytoplasmic in lung SCCs, but nuclear in ACs $(50,53,54)$. We therefore regarded nuclear and/or cytoplasmic maspin immunoreactivity as positive staining. We found both cytoplasmic and nuclear positivity at a higher rate in SCC cases. However, maspin positivity was only nuclear in two tumors, only cytoplasmic in four tumors, and both nuclear and cytoplasmic in two tumors in our AC group.

Several studies have emphasized the clinicopathological importance of nuclear and cytoplasmic distribution of maspin in various tumors. Nuclear positivity is thought to be a good prognostic indicator in lung ACs but cytoplasmic staining has been associated with shorter survival in some studies $(49,53,55,56)$. Sood at al. (45) reported that cytoplasmic localization is related to a poor prognosis in ovarian carcinomas while nuclear localization is associated with more benign pathology. They emphasized that the nuclear localization of maspin possibly represents the active form and is likely to have an important tumor suppressive role.

A study where nuclear and cytoplasmic staining was accepted as positive found that five-year survival of lung NSCLCs was markedly increased with higher maspin expression (8). Nakashima et al. (9) reported that five-year survival was better in the maspin-positive lung AC group. However, another study reports that maspin does not affect survival in lung NSCLCs (50). Nakagawa et al. (48) and Wu et al. (52) demonstrated that nuclear and/or cytoplasmic maspin staining was a good prognostic factor in SCCs. Takanami et al. (57) similarly reported that strong maspin expression increased the survival duration in SCCs.
Maspin positivity did not affect the overall survival in our SCC group but had an additive effect on the survival of AC cases. Based on our results, we believe that nuclear maspin represents the active form of the molecule as stated by Sood et al. (45).

Previous studies have reported that p63 and p53 control maspin expression by transactivating the promoter $(54,58)$. The differential expression of maspin in carcinoma-derived lung cancer cells and cancer tissues has been shown to be dependent on the presence of p63. It has been suggested that TAp63 might be a novel stimulator of the maspin promoter in lung cancer. Both p63 and maspin were highly positive in SCCs. p63 was negative in ACs, whereas maspin was positive at a lower rate in ACs compared to SCCs. Furthermore, maspin expression has been discovered to be associated with lymph node involvement and tumor stage, except in squamous carcinoma (54). We similarly found higher positive rates for p63 and maspin in the SCC group. All these findings suggest maspin may play an important role in studying and developing personalized targeted therapies for lung cancer.

We established on multivariate analysis that tumor diameter is the only factor affecting overall survival. Nevertheless, our multivariate analysis results may be limited due to the relatively low number of cases in our study.

In conclusion, p63 and TTF- 1 are two reliable IHC markers for the differential diagnosis of lung carcinoma. On the other hand, maspin could be used as an immunohistochemical marker to help anticipate survival. More detailed studies are required for clarification of the subject.

\section{ACKNOWLEDGEMENT}

The authors thank Hatice Uluer for statistical analyses.

\section{FUNDING SOURCE}

This study was supported by grants from Ege University Scientific Research Fund.

\section{REFERENCES}

1. Olak J, Colson Y. Gender differences in lung cancer: Have we really come a long way, baby? Thorac Cardiovasc Surg. 2004;128:34651.

2. William D. Travis, Elisabeth Brambilla, H. Konrad MüllerHermelink, Curtis C. Harris. Pathology and genetics of tumors of the lung, pleura, thymus and heart. Kleihues P, Sobin LH, editors. Lyon: IARC;2004 
3. Massion PP, Taflan PM, Jamshedur Rahman SM, Yildiz P, Shyr Y, Edgerton ME, Westfall MD, Roberts JR, Pietenpol JA, Carbone DP, Gonzalez AL. Significance of p63 amplification and overexpression in lung cancer development and prognosis. Cancer Res. 2003;63:7113-21.

4. Wang BY, Gil J, Kaufman D, Gan L, Kohtz DS, Burstein DE. P63 in pulmonary epithelium, pulmonary squamous neoplasms, and other pulmonary tumors. Hum Pathol. 2002;33:921-6.

5. Afify AM, al-Khafaji BM. Diagnostic utility of thyroid transcription factor-1 expression in adenocarcinomas presenting in serous fluids. Acta Cytol. 2002;46:675-8.

6. Di Loreto C, Di Lauro V, Puglisi F, Damante G, Fabbro D, Beltrami CA. Immunocytochemical expression of tissue specific transcription factor-1 in lung carcinoma. J Clin Pathol. 1997;50:30-2.

7. Smith SL, Watson SG, Ratschiller D, Gugger M, Betticher DC, Heighway J. Maspin - the most commonly-expressed gene of the $18 \mathrm{q} 21.3$ serpin cluster in lung cancer - is strongly expressed in preneoplastic bronchial lesions. Oncogene. 2003;22:8677-87.

8. Katakura H, Takenaka K, Nakagawa M, Sonobe M, Adachi M, Ito $\mathrm{S}$, Wada $\mathrm{H}$, Tanaka $\mathrm{F}$. Maspin gene expression is a significant prognostic factor in resected non-small cell lung cancer (NSCLC). Maspin in NSCLC. Lung Cancer. 2006;51:323-8.

9. Nakashima M, Ohike N, Nagasaki K, Adachi M, Morohoshi T. Prognostic significance of the maspin tumor suppressor gene in pulmonary adenocarcinoma. J Cancer Res Clin Oncol. 2004;130:475-9.

10. $\mathrm{Au} \mathrm{NH}$, Cheang M, Huntsman DG, Yorida E, Coldman A, Elliott WM, Bebb G, Flint J, English J, Gilks CB, Grimes HL. Evaluation of immunohistochemical markers in non-small cell lung cancer by unsupervised hierarchical clustering analysis: A tissue microarray study of 284 cases and 18 markers. J Pathol. 2004;204:101-9.

11. Berghmans T, Mascaux C, Martin B, Ninane V, Sculier JP. Prognostic role of thyroid transcription factor-1 in stage III nonsmall cell lung cancer. Lung Cancer. 2006;52:219-24.

12. Goksel T, Akkoclu A. Pattern of lung cancer in Turkey, 19941998. Respiration. 2002;69:207-10.

13. Hirsch FR, Franklin WA, Gazdar AF, Bunn PA Jr. Early detection of lung cancer: Clinical perspectives of recent advances in biology and radiology. Clin Cancer Res. 2001;7:5-22.

14. Brundage MD, Davies D, Mackillop WJ. Prognostic factors in non-small cell lung cancer: A decade of progress. Chest. 2002;122:1037-57.

15. Ou SH, Zell JA, Ziogas A, Anton-Culver H. Prognostic factors for survival of stage I nonsmall cell lung cancer patients: A populationbased analysis of 19,702 stage I patients in the California Cancer Registry from 1989 to 2003. Cancer. 2007;110:1532-41.

16. Irwin MS, Kaelin WG Jr. Role of the newer p53 family proteins in malignancy. Apoptosis. 2001;6:17-29.

17. Yang A, Kaghad M, Wang Y, Gillett E, Fleming MD, Dötsch V, Andrews NC, Caput D, McKeon F. p63, a p53 homolog at 3q27-29, encodes multiple products with transactivating, death-inducing, and dominant-negative activities. Mol Cell. 1998;2:305-16.
18. Brunner HG, Hamel BC, Bokhoven Hv H. P63 gene mutations and human developmental syndromes. Am J Med Genet. 2002;112:284-90.

19. Au NH, Gown AM, Cheang M, Huntsman D, Yorida E, Elliott WM, Flint J, English J, Gilks CB, Grimes HL. P63 expression in lung carcinoma: A tissue microarray study of 408 cases. Appl Immunohistochem Mol Morphol. 2004;12:240-7.

20. Kaufmann O, Fietze E, Mengs J, Dietel M. Value of p63 and cytokeratin $5 / 6$ as immunohistochemical markers for the differential diagnosis of poorly differentiated and undifferentiated carcinomas. Am J Clin Pathol. 2001;116:823-30.

21. Pelosi G, Pasini F, Olsen Stenholm C, Pastorino U, Maisonneuve P, Sonzogni A, Maffini F, Pruneri G, Fraggetta F, Cavallon A, Roz E, Iannucci A, Bresaola E, Viale G. p63 immunoreactivity in lung cancer: Yet another player in the development of squamous cell carcinomas? J Pathol. 2002;198:100-9.

22. Wu M, Wang B, Gil J, Sabo E, Miller L, Gan L, Burstein DE. p63 and TTF-1 immunostaining. A useful marker panel for distinguishing small cell carcinoma of lung from poorly differentiated squamous cell carcinoma of lung. Diagn Cytopathol. 2003;119:696-702.

23. Iwata $T$, Uramoto $H$, Sugio K, Fujino Y, Oyama T, Nakata S, Ono K, Morita M, Yasumoto K. A lack of prognostic significance regarding DeltaNp63 immunoreactivity in lung cancer. Lung Cancer. 2005;50:67-73.

24. Shtilbans V, Szporn AH, Wu M, Burstein DE. p63 immunostaining in destained bronchoscopic cytological specimens. Diagn Cytopathol. 2005;32:198-203.

25. Wu M, Szporn AH, Zhang D, Wasserman P, Gan L, Miller L, Burstein DE. Cytology applications of p63 and TTF-1 immunostaining in differential diagnosis of lung cancers. Diagn Cytopathol. 2005;33:223-7.

26. Camilo R, Capelozzi VL, Siqueira SA, Del Carlo Bernardi F. Expression of p63, keratin 5/6, keratin 7 , and surfactant-A in non-small cell lung carcinomas. Hum Pathol. 2006;37:542-6.

27. Kargi A, Gurel D, Tuna B. The diagnostic value of TTF-1, CK 5/6, and p63 immunostaining in classification of lung carcinomas. Appl Immunohistochem Mol Morphol. 2007;15:415-20.

28. Koh J, Go H, Kim MY, Jeon YK, Chung JH, Chung DH. A comprehensive immunohistochemistry algorithm for the histological subtyping of small biopsies obtained from non-small cell lung cancers. Histopathology. 2014;65:868-78.

29. Xu XY, Yang GY, Yang JH, Li J. Analysis of clinical characteristics and differential diagnosis of the lung biopsy specimens in 99 adenocarcinoma cases and 111 squamous cell carcinoma cases: Utility of an immunohistochemical panel containing CK5/6, CK34betaE12, p63, CK7 and TTF-1. Pathol Res Pract. 2014;210:680-5.

30. Shah L, Walter KL, Borczuk AC, Kawut SM, Sonett JR, Gorenstein LA, Ginsburg ME, Steinglass KM, Powell CA. Expression of syndecan-1 and expression of epidermal growth factor receptor are associated with survival in patients with nonsmall cell lung carcinoma. Cancer. 2004;101:1632-8. 
31. Pu RT, Pang Y, Michael CW. Utility of WT-1, p63, MOC31, mesothelin, and cytokeratin (K903 and CK5/6) immunostains in differentiating adenocarcinoma, squamous cell carcinoma, and malignant mesothelioma in effusions. Diagn Cytopathol. 2008;36:20-5.

32. Brunnstrom H, Johansson L, Jirstrom K, Jonsson M, Jonsson P, Planck M. Immunohistochemistry in the differential diagnostics of primary lung cancer: An investigation within the Southern Swedish Lung Cancer Study. Am J Clin Pathol. 2013;140:37-46.

33. Hiroshima K, Iyoda A, Shida T, Shibuya K, Iizasa T, Kishi H, Tanizawa T, Fujisawa T, Nakatani Y. Distinction of pulmonary large cell neuroendocrine carcinoma from small cell lung carcinoma: A morphological, immunohistochemical, and molecular analysis. Mod Pathol. 2006;19:1358-68.

34. Zhang H, Liu J, Cagle PT, Allen TC, Laga AC, Zander DS. Distinction of pulmonary small cell carcinoma from poorly differentiated squamous cell carcinoma: An immunohistochemical approach. Mod Pathol. 2005;18:111-8.

35. Kalhor N, Zander DS, Liu J. TTF-1 and p63 for distinguishing pulmonary small-cell carcinoma from poorly differentiated squamous cell carcinoma in previously pap-stained cytologic material. Mod Pathol. 2006;19:1117-23.

36. Tan D, Li Q, Deeb G, Ramnath N, Slocum HK, Brooks J, Cheney R, Wiseman S, Anderson T, Loewen G. Thyroid transcription factor-1 expression prevalence and its clinical implications in non-small cell lung cancer: A high-throughput tissue microarray and immunohistochemistry study. Hum Pathol. 2003;34:597604.

37. Reynolds PR, Mucenski ML, Whitsett JA. Thyroid transcription factor (TTF) -1 regulates the expression of midkine (MK) during lung morphogenesis. Dev Dyn. 2003;227:227-37.

38. Myong NH. Thyroid transcription factor-1 (TTF-1) expression in human lung carcinomas: Its prognostic implication and relationship with wxpressions of p53 and Ki-67 proteins. J Korean Med Sci. 2003;18:494-500.

39. Jerome Marson V, Mazieres J, Groussard O, Garcia O, Berjaud J, Dahan M, Carles P, Daste G. Expression of TTF-1 and cytokeratins in primary and secondary epithelial lung tumours: Correlation with histological type and grade. Histopathology. 2004;45:125-34.

40. Johansson L. Histopathologic classification of lung cancer: Relevance of cytokeratin and TTF-1 immunophenotyping. Ann Diagn Pathol. 2004;8:259-67.

41. Stenhouse G, Fyfe N, King G, Chapman A, Kerr KM. Thyroid transcription factor 1 in pulmonary adenocarcinoma. J Clin Pathol. 2004;57:383-7.

42. Chang YL, Lee YC, Liao WY, Wu CT. The utility and limitation of thyroid transcription factor-1 protein in primary and metastatic pulmonary neoplasms. Lung cancer. 2004;44:149-57.

43. Srodon M, Westra WH. Immunohistochemical staining for thyroid transcription factor-1: A helpful aid in discerning primary site of tumor origin in patients with brain metastases. Hum Pathol. 2002;33:642-5.

44. Yatabe Y, Mitsudomi T, Takahashi T. TTF-1 expression in pulmonary adenocarcinomas. Am J Surg Pathol. 2002;26:767-73.
45. Sood AK, Fletcher MS, Gruman LM, Coffin JE, Jabbari S, Khalkhali-Ellis Z, Arbour N, Seftor EA, Hendrix MJ. The paradoxical expression of maspin in ovarian carcinoma. Clin Cancer Res. 2002; 8:2924-32.

46. Bailey CM, Khalkhali-Ellis Z, Seftor EA, Hendrix MJ. Biological functions of maspin. J Cell Physiol. 2006; 209:617-24.

47. Bailey CM, Khalkhali-Ellis Z, Kondo S, Margaryan NV, Seftor RE, Wheaton WW, Amir S, Pins MR, Schutte BC, Hendrix MJ. Mammary serine protease inhibitor (Maspin) binds directly to interferon regulatory factor 6: Identification of a novel serpin partnership. J Biol Chem. 2005; 280:34210-7.

48. Nakagawa M, Katakura H, Adachi M, Takenaka K, Yanagihara K, Otake Y, Wada H, Tanaka F. Maspin expression and its clinical significance in non-small cell lung cancer. Ann Surg Oncol. 2006;13:1517-23.

49. Hirai K, Koizumi K, Haraguchi S, Hirata T, Mikami I, Fukushima M, Yamagishi S, Kawashima T, Okada D, Shimizu K, Kawamoto M. Prognostic significance of the tumor suppressor gene maspin in non-small cell lung cancer. Ann Thorac Surg. 2005;79:248-53.

50. Woenckhaus M, Bubendorf L, Dalquen P, Foerster J, Blaszyk H, Mirlacher M, Soler M, Dietmaier W, Sauter G, Hartmann A, Wild PJ. Nuclear and cytoplasmic Maspin expression in primary nonsmall cell lung cancer. J Clin Pathol. 2007;60:483-6.

51. Bircan A, Bircan S, Kapucuoglu N, Songur N, Ozturk O, Akkaya A. Maspin, VEGF and p53 expression in small biopsies of primary advanced lung cancer and relationship with clinicopathologic parameters. Pathol Oncol Res. 2010;16:553-61.

52. Wu S, Yu L, Cheng Z, Song W, Zhou L, Tao Y. Expression of maspin in non-small cell lung cancer and its relationship to vasculogenic mimicry. J Huazhong Univ Sci Technolog Med Sci. 2012;32:346-52.

53. Lonardo F, Li X, Siddiq F, Singh R, Al-Abbadi M, Pass HI, Sheng S. Maspin nuclear localization is linked to favorable morphological features in pulmonary adenocarcinoma. Lung Cancer. 2006;51:31-9.

54. Kim S, Han J, Kim J, Park C. Maspin expression is transactivated by p63 and is critical for the modulation of lung cancer progression. Cancer Res. 2004;64:6900-5.

55. Berardi R, Santinelli A, Onofri A, Brunelli A, Pierantoni C, Pisa E, Pagliacci A, Stramazzotti D, Zuccatosta L, Mazzanti P, Sabbatini A, Gasparini S, Bearzi I, Cascinu S. Maspin expression is a favorable prognostic factor in non-small cell lung cancer. Anal Quant Cytol Histol. 2012;34:72-8.

56. Takagi Y, Matsuoka Y, Shiomi T, Nosaka K, Takeda C, Haruki T, Araki K, Taniguchi Y, Nakamura H, Umekita Y. Cytoplasmic maspin expression is a predictor of poor prognosis in patients with lung adenocarcinoma measuring $<3 \mathrm{~cm}$. Histopathology. 2015; 66:732-9.

57. Takanami I, Abiko T, Koizumi S. Expression of maspin in nonsmall-cell lung cancer: Correlation with clinical features. Clin Lung Cancer. 2008;9:361-6.

58. Choy B, Findeis-Hosey JJ, Li F, McMahon LA, Yang Q, Xu H. High frequency of coexpression of maspin with p63 and p53 in squamous cell carcinoma but not in adenocarcinoma of the lung. J Clin Exp Pathol. 2013;6:2542-7. 